\title{
O DEVER FUNDAMENTAL DO EXECUTADO DE NOMEAR BENS PASSÍVEIS DE PENHORA
}

\author{
THE FUNDAMENTAL DUTY OF THE EXECUTED \\ TO APPOINT GOODS SUBJECT TO ATTACHMENT
}

\author{
Alexandre Grandi Mandelli* \\ Christian Frau Obrador Chaves**
}

\begin{abstract}
RESUMO: A ideia de uma concepção cooperativa do processo civil - tema que começa a inspirar relevante produção científica na doutrina brasileira - suscita um olhar renovado sobre os institutos processuais, um ponto de vista que considere os aportes teóricos da fase metodológica atual da ciência processual. Busca-se neste artigo demonstrar o importante papel desenvolvido pelos "atores do processo", aqui incluem-se tanto as partes como o juiz e seus auxiliares, em nome da célere e efetiva prestação da tutela jurisdicional. Num primeiro momento, traz-se à baila mecanismo tradicional, característico do ordenamento processual anglo-saxônico, conhecido como Discovery. Adentra-se no tormentoso espaço do processo cooperativo como modelo de processo do Estado Constitucional de Direito, ou como denomina a Constituição Federal de 1988, Estado Democrático de Direito, para, então, chegarmos ao ponto nevrálgico deste estudo que é o dever de colaboração do executado de nomear bens passíveis de penhora. $\mathrm{O}$ objeto, portanto, é o de investigar as consequências de uma visão cooperativa, no que respeita à efetividade da tutela dispensada no processo de cunho eminentemente constitucional.
\end{abstract}

PALAVRAS-CHAVE: Dever de colaboração. Nomeação de bens à Penhora. Tutela jurisdicional efetiva.

ABSTRACT: The idea of a cooperative design of civil procedure - a theme that is beginning to inspire teaching in the relevant scientific production in Brazil - creates a fresh look at the institutes proceedings in a perspective that considers the theoretical contributions of the current phase of the methodological process science. Search-This paper highlights the important role played by "actors in the process," here include both parties as the judge and his staff on behalf of the delivery of swift and effective judicial protection. At first, it brings into question the traditional mechanism, characteristic of Anglo-American procedural law, known as Discovery. Enters in the stormy process space as a cooperative process model of state constitutional law, or as called the Constitution of 1988, a democratic state, to then get to the crux of this study is the duty of collaboration to appoint the property which runs the attachment. The object therefore is to investigate the consequences of a cooperative vision, regarding the effectiveness of the protection given in the process eminently constitutional.

KEYWORDS: Duty to cooperate. Nomination of property to be attached. Effective judicial protection.

* Mestrando em Direito Público - PUCRS. Especialista em direito processual civil - PUCRS. Advogado. E-mail: amandelli@gmail.com

** Mestrando em Direito Público - PUCRS. Procurador da Fazenda Nacional de $1^{\text {a }}$ Categoria. E-mail: christian.chaves@pgfn.gov.br 


\section{INTRODUÇÃO}

A Inglaterra foi o berço do chamado adversary system. Na verdade, coexistiram no país, durante muito tempo, dois sistemas de administração da justiça: o do common law e o da equity, com características diferentes ${ }^{1}$. As notas básicas, na concepção de Barbosa Moreira, desse sistema são: (a) divisão nítida do procedimento em duas fases: a sessão de julgamento (trial) - em teoria, ${ }^{2}$ o ponto culminante do trajeto - e a fase preparatória (pre-trial); (b) atuação judicial limitada ao trial, sem prévio controle da atividade processual e até sem prévio conhecimento da causa por parte do juiz; (c) predomínio das provas orais e concentração da respectiva produção; (d) atribuição do controle do andamento do pleito e da coleta de provas aos próprios litigantes, ou mais exatamente a seus advogados (expressão-chave: passividade do juiz); (e) por conseguinte, escassa (ou nenhuma) preocupação com a coincidência entre os fatos tais como apresentados pelas partes ao órgão judicial e os fatos tais como realmente se passaram. (MOREIRA, 2011)

A preferência pela oralidade e a feição concentrada da instrução probatória seriam condizentes com o tipo de pessoas a quem se confiava a decisão sobre os fatos - iletradas, dificilmente habilitadas para examinar e compreender documentos - e à maneira pela qual se desincumbiam da função - reunidas para a realização de tarefa que naturalmente preferiam ultimar com a maior rapidez possível, a fim de se liberarem para a volta aos respectivos lares e atividades habituais. Esse método de trabalho explicaria também a ausência de qualquer controle judicial anterior ao julgamento (pre-trial) e a inibição do juiz na instrução probatória, considerada que era qualquer intervenção do magistrado em tal domínio como ofensiva à soberania do júri.

Característico do ordenamento processual anglo-saxônico, esse mecanismo é tradicionalmente conhecido como discovery, mediante o qual cada uma das partes pode munir-se de provas a que de ordinário não teria acesso, principalmente documentos do adversário. Tal possibilidade abre perspectiva de êxito, por exemplo, a quem litigue contra grandes empresas e necessite inteirar-se de suas atividades; por outro lado, favorece a solução consensual do litígio, na medida em que permite aos litigantes avaliar com realismo a solidez de sua posição.

Discovery, como sugere a tradução literal, descoberta, atua no campo probatório, municiando as partes de ferramentas essenciais para uma robusta e futura discussão

1 Bom resumo da origem e evolução do sistema da equity, com indicação das principais diferenças entre o respectivo funcionamento e o dos tribunais de common law, em HANBURY-YARDLEY, English Courts of Law, Oxford, 1979, p. 93 e ss.

2 Em teoria: impõe-se a ressalva porque, ao menos em tempos modernos, só pequena percentagem dos feitos estende-se até o trial; a maioria termina sem ele, em virtude de acordo ou por outros motivos. Vide, por exemplo, JACOB, The Fabric of English Civil Procedure, Londres, 1987, p. 71. 
judicial (trial). Tal mecanismo ampara-nos e instiga o jurista a adentrar nos meadros da colaboração das partes em busca da justa solução da lide. O instituto da Discovery, aparentemente, pretende, com o seu pre-trial, atingir um consenso entre as partes antes de o Estado-Juiz prolatar qualquer provimento jurisdicional. O juiz exerce um papel meramente secundário (passivo), haja vista que na fase de pré-julgamento não possui ingerência sobre a produção da prova.

Certo é que o instituto da Discovery, diferentemente do exposto em nosso Estatuto Processual, em seu artigo 339, delega a busca da verdade às partes, desincumbindo o Poder Judiciário de tal desiderato, o que na Civil Law não há como se admitir; além do mais, quando se advoga por um dever de colaboração de todos os "atores do processo". Todos, partes, juiz e auxiliares, devem trilhar o caminho da cooperação.

Nessa esteira, podemos trazer à colação a positivação dos deveres de lealdade, de boa-fé e de cooperação para com a realização da Justiça (princípio da cooperação - artigos 645 da CLT e 339 do CPC). O dever de cooperação pelo executado compreende a obrigação de indicação dos bens aptos à satisfação da obrigação (CPC, art. 600, IV), sob as penas dos artigos 14, parágrafo único, 601 e 18 do CPC. A relevância desse dever processual é notória, pois a maior dificuldade da execução reside na localização dos bens. Manifesta, portanto, a importância da correta compreensão e utilização desse dever do executado como instrumento de promoção dos direitos à efetividade e à razoável duração do processo (CF, art. 5º, XXXV e LXXVIII).

\section{O MECANISMO TRADICIONAL, CARACTERÍSTICO DO ORDENAMENTO PROCESSUAL ANGLO-SAXÔNICO, CONHECIDO COMO DISCOVERY}

O princípio dispositivo, que integra o direito processual civil brasileiro, é compreendido fundamentalmente na iniciativa do autor de inaugurar o processo e as alegações que o integrarão. Destarte, a transação e a renúncia do direito objeto da ação são exemplos da autonomia exclusiva das partes que vigora no sistema brasileiro.

Entretanto, não apenas as partes são incumbidas de desenvolver o processo, o juiz, igualmente, mostra-se figura importante e, em alguns casos, ativa na atuação processual. A direção formal e material do processo é delineada sob impulso oficial, conforme reza o art. 262, segunda parte, do Código de Processo civil brasileiro. Com efeito, excetuando os casos em que as partes exercem poderes exclusivos, o órgão judiciário pode exercer poderes de iniciativa própria (p. ex.: iniciativa do juiz em requerer $\left.\operatorname{provas}^{3}\right)$.

3 No que tange ao magno problema da iniciativa de reunir e ministrar as provas tendentes a confirmar, ou não, as alegações das partes, o órgão judiciário brasileiro dispõe de poderes irrestritos. O juiz pode ordenar a produção de qualquer prova (art. 130 do CPC), ex officio, incumbindo ao autor antecipar as respectivas despesas (art. 19, § $2^{\circ}, \mathrm{d}$ o $\mathrm{CPC}$ ). Por exemplo, o juiz poderá valer-se do tão enaltecido quanto esquecido interrogatório 


\section{Araken de Assis assevera:}

A esse propósito, costuma-se identificar dois grandes sistemas, utilizando-se as expressões inglesas inquisitorial, para retratar o vigorante na Civil Law, e adversarial, para designar o predominante na Common Law. Neste último, as partes figuram como protagonistas exclusivos na tarefa de propor e de produzir as provas, atividade chamada de discovery, a cargo, precipuamente, dos respectivos advogados. Não é possível, entretanto, traçar uma fronteira tão radical entre os dois sistemas. Reformas legislativas aumentaram o controle do juiz no direito norte-americano, coibindo a investigação com o intuito de molestar, constranger, oprimir e asfixiar a parte contrária, sob o pretexto de coligir elementos para futura demanda. E a iniciativa das partes, nesta seara subsiste nos Países da Civil Law: não é incomum, por exemplo, o futuro autor providenciar laudo técnico para subsidiar suas alegações nas ações de reparação de dano. Porém, a filiação do direito brasileiro ao regime inquisitorial é evidente, situando-se quase na contramão da tendência de reduzir o caráter público do processo civil. Entre nós, para usar a síntese alemã, vigora a Inquisitionsmaxime, e, não, a Verhandlungsmaxime, segundo a qual só às partes, por meio do debate, compete produzir as provas idôneas à demonstração dos fatos, pré-excluindo a iniciativa do juiz. (ASSIS, 2011)

Cumpre destacar que apesar do sistema brasileiro primar pelo sistema inquisitorial, o juiz está longe de ser um "sujeito ativo" processual. "Em geral, o órgão judiciário abstém-se de conduzir mais firmemente o processo ou de envolver-se na pesquisa do material de fato." (ASSIS, 2011)

Importante trazer à baila a ideia da "jurisdição como regulação de uma relação interpessoal por um terceiro imparcial". (TESHEINER, 2010, p. 84)

$\mathrm{O}$ conteúdo jurisdicional compreende-se na jurisdição civil, em que o magistrado regula e determina os direitos e deveres entre as pessoas. (TESHEINER, 2010, p. 85) Assim, "pode-se apontar, como elemento formal da jurisdição, a circunstância de emanar tal regulação de um órgão “independente e imparcial'." (TESHEINER, 2010, p. 85) Frisa-se que este requisito formal é a essência da Jurisdição.

Com efeito, apesar de o juiz dever primar pela imparcialidade, nada impede que seja um "sujeito processual ativo", diferente do juiz neutro. Ao passo, Araken de Assis, seguindo esta linha de pensamento, critica a atuação atual do órgão judiciário: “o contundente arsenal do órgão judiciário permanece armazenado em lugar distante da liça judiciária. ${ }^{4} \mathrm{Na}$ melhor das hipóteses, o juiz emprega o estoque de armas participativas com excessiva parcimônia”. (ASSIS, 2011).

para esclarecimento, previsto no art. 342 do CPC. E não convém olvidar que, nas causas em que se sobreleva o interesse público (art. 82, III, do CPC), intervém o Ministério Público, que é outro órgão do Estado, cujos poderes se equiparam aos das partes (art. 81 do CPC). (ASSIS, 2011).

4 Essa inércia do órgão judiciário se explica por alguns fatores. $\mathrm{O}$ principal é a quantidade de feitos, fato que impede a análise atenta da maioria dos casos e, conseguintemente, a tomada das resoluções ex officio que interessariam à causa. Raros juízes, por exemplo, estudaram o processo de antemão e, na audiência preliminar, encontram-se habilitados a fixar os pontos controvertidos, resolver as questões incidentais e determinar "as provas a serem produzidas", como estipula o art. 331. (ASSIS, 2011). 
Por outra banda, deixando de lado, por ora, a análise do sistema brasileiro, importante trazer à baila o sistema adversarial, que vigora na Common Law e funda-se principalmente no instituto da discovery.

Ensina Michele Taruffo:

However, all the common law systems Begin with a concept of the adversary system, which defines the roles of the judge and the parties advocates. The definitions of these roles in common law systems are traditionally, and at least nominally, similar. That is, the role of the judge is to decide between competing presentations of evidence and law that are tendered by the advocates. The corresponding role of the advocates is to develop and make those presentations. The judge is not responsible for there being an adequate development of the evidence during trial and a fortiori is not responsible for there being adequate pretrial discovery of evidence. Nor is the judge responsible for getting at "the truth". The judge simply chooses between the contentions of law and the versions of facts laid before him by the parties.(TARUFFO, 1998, p. 1019). ${ }^{5}$

Com efeito, o processo de litigância nos países que adotam a Common Law "consiste em dois componentes estanques, porém interdependentes: o estágio "pre-trial" e o "trial" propriamente dito." (CARVALHO FILHO, 2011) Assim, deve-se destacar, antes de mais nada, que o processo civil no sistema anglo-saxão "respeita o conceito de devido processo legal, pois as partes possuem diversas garantias que são respeitadas, principalmente na fase do "trial" ou julgamento, tais como o contraditório e a ampla defesa." (CARVALHO FILHO, 2011)

Antônio Carvalho Filho ensina:

A fase "pre-trial" existe para que se possa, entre outras coisas, reduzir o crescimento vertiginoso de "trial" e para esclarecer os fatos e argumentos que serão instruídos no julgamento. Essa fase possui duas modalidades de busca de provas, que, nesta altura, são consideradas evidências ou indícios, quais sejam: o "discovery" e o "deposition", que corresponde à tomada de depoimento de qualquer pessoa em qualquer momento e por qualquer interlocutor. Lembramos que o "discovery" trata de todas as matérias que não se relacionem com a prova verbal, tendo como incidência principal os documentos. O "trial", ou julgamento propriamente dito, é o componente central do processo de litigância nos Estados Unidos, o qual é necessariamente contínuo. Isso significa que há, geralmente, mínimas possibilidades para se descobrir novos fatos, ou produzir novas provas, durante o curso do julgamento. Por decorrência lógica, cada parte deve estar com seu "caso" preparado antes do "trial". (CARVALHO FILHO, 2011)

5 Tradução livre: "No entanto, todos os sistemas de common law começam com um conceito do sistema adversário, que define o papel do juiz, das partes e seus advogados. As definições dessas funções no sistema de common law são tradicionalmente, e pelo menos nominalmente, semelhantes. Ou seja, o papel do juiz é decidir entre apresentações concorrentes de provas e de direito que são oferecidas pelos advogados. O papel dos advogados correspondentes é desenvolver e fazer as apresentações. O juiz não é responsável pela existência de um adequado desenvolvimento das provas durante o julgamento e, a fortiori, não é responsável para que haja adequada descoberta preventiva de provas. Também não é o juiz responsável por obter a "verdade". O juiz simplesmente escolhe entre as alegações de direito e as versões dos fatos estabelecidos diante dele pelas partes." 
Nessa senda, o sistema jurisdicional da common law é formado por 12 (doze) jurados que deverão decidir de forma unânime a controvérsia. Destarte, o conselho de jurados é o verdadeiro juiz da causa e tem o poder de dizer o direito. "O seu papel é decidir questões de fato e aplicar o direito ao caso concreto de acordo com as instruções do juiz presidente, que não participa da decisão dos jurados." (CARVALHO FILHO, 2011).

\section{Com efeito, assevera Michele Taruffo:}

A derivative of this fundamental premise about the roles of judge and advocates is that the civil law system has no "pretrial", let alone pretrial discovery. "Pre" trial implies an adjudication process with at least two stages, pretrial and then trial itself. The need for a two-stage process in evident in an adjudicative system based on jury trial. A jury is an assemblage constituted ad hoc whose members need not be convened until their time on the stage has arrived, and who should go home when their role has been played. The jurors decide facts, not legal questions, and the rendition of their verdict constitutes fulfillment of that function. Efficient use of a jury's time requires that presentation of the evidence be concentrated in a single continuous session. Such a concentrated session is the "trial"; everything prior to trial is "pretrial". According to modern legal standards, the parties to the litigation should have opportunity to know somewhat beforehand - in a preview, so to speak - the substance of the opposing party's proof. That opportunity includes time to think over that evidence and to arrange to counter it so far as possible. Because a jury trial is to be a concentrated session, opportunity for such a preview must be afforded somewhat before the jury session commences. Hence, pretrial discovery is a logical necessity in a modern system based on jury trial, if the premise is accepted that litigants should have a preview of the countries other than the United States no longer use juries very much. Nevertheless, they adhere to the tradition of concentrated trial procedure. By the same token, they adhere more or less to the need for pretrial discovery. (TARUFFO, 1998, p.1020). ${ }^{6}$

${ }^{6}$ Tradução livre: "Um derivado dessa premissa fundamental sobre os papéis de juiz e advogados é que o sistema da civil law não tem "pré-julgamento", muito menos antes do julgamento. "Pré" julgamento implica um processo de adjudicação com pelo menos duas fases, pré-julgamento e depois o próprio julgamento. A necessidade de um processo de dois estágios é evidente em um sistema judicante com base no julgamento do júri. Um júri é um conjunto constituído ad hoc, cujos membros não precisam ser convocados enquanto seu momento de subir ao palco não tenha chegado e que deveria ir para casa assim que o seu papel for desempenhado. Os jurados decidem fatos, não questões jurídicas, e as entregas de seu veredicto constituem o cumprimento dessa função. $\mathrm{O}$ uso eficiente do tempo de um júri pede para que a apresentação da documentação seja concentrada em uma única sessão contínua. Tal sessão concentrada é o "julgamento", tudo antes do julgamento é a "preventiva" De acordo com modernos padrões legais, as partes em litígio devem ter oportunidade de conhecer um pouco antes - em uma previsão, por assim dizer - o conteúdo da prova do oponente. Essa oportunidade inclui tempo para pensar mais sobre as provas e organizar-se para enfrentá-la na medida do possível. Porque um júri deve ser uma sessão concentrada, oportunidade para tal previsão deve ser concedida tanto antes do início da sessão de júri. Assim, descoberta prévia do julgamento é uma necessidade lógica em um sistema moderno baseado em tribunal do júri, se a premissa é aceita que os litigantes devem ter uma prévia dos outros países que não os Estados Unidos que não mais usam muito os júris. No entanto, eles aderem à tradição do procedimento do julgamento concentrado. Pela mesma razão, eles aderem mais ou menos à necessidade para a descoberta de pré-julgamento.” 
Diferentemente do sistema adotado pela Civil $\mathrm{Law}^{7}$, o juiz anglo-saxão age como um mediador entre as partes. "Raramente questiona testemunhas, ou participa na apresentação de fatos no processo. Ele define as normas processuais que serão aplicadas, porém possui poucos poderes na determinação dos fatos." (CARVALHO FILHO, 2011).

Nessa quadra, Antônio Carvalho Filho completa:

Voltando à questão central, o "pre-trial discovery" é disciplinado pelo Federal Rules of Civil Procedure, precisamente pelos Rules 26, 29, 34, 35, 36 e 37. Tendo isso em conta, podemos definir "pre-trial discovery" (de documentos, como chamado na Convenção de Haia de 1970) como um procedimento inquisitório em que as partes, sem a interferência do juiz, têm possibilidades, antes do início do julgamento, de colher, sem coerção, determinado tipo de evidências ou indícios, nomeadamente documentos, que estejam em poder da contra-parte ou de terceiro, possibilitando a preparação para o julgamento, o qual é contínuo e impossibilita a "descoberta" de novas provas que possam interessar ao deslinde da causa. Caso a parte requisitada para apresentar um documento não o faça, a parte requisitante pode pedir ao juiz que determine a apresentação do documento desejado. O procedimento "pre-trial discovery", também conhecido como "fishing expedition", caracteriza-se como uma "aventura" em que a parte requisitante "lança a isca", ou seja, a requisição à outra parte e não tem certeza do que irá obter, ou "pescar". Por razões óbvias, o procedimento de "pre-trial", como conhecido nos países de common law, é completamente desconhecido aos países que adotam o sistema civil law, sendo, em nossa opinião, incompatível com os procedimentos utilizados nesses Estados. (CARVALHO FILHO, 2011).

7 "The premise in civil law jurisdictions is entirely different, at least formally so. Under the civil law procedural systems, the judge is responsible for deciding a case according to the truth of the matter. The judge decides both fact and law because there is no jury or anything like it. It is assumed that the truth of the matter will be revealed by relevant evidence. Under the civil law, it therefore follows that the judge is responsible for eliciting relevant evidence. The parties in civil law litigation are represented by advocates, and the advocates are empowered and obligated to assist their clients in presenting their respective sides of the case. However, in principle, the advocates function is to assist the judge in fulfillment of the judicial responsibility, rather than, as in the common law, the judge being responsible only in terms of the advocates previously exercised responsibilities of presentation. In the civil law concept, the advocates are supposed to provide comment and suggestions to the judge, with a deference which varies from one civil law jurisdiction to another. But at least in theory they have no power of initiative after they have presented the claims and defenses in the pleadings, except with the assent of the judge." (TARUFFO, 1998, p. 1019-1020). Tradução livre: “A premissa em jurisdições de civil law é totalmente diferente, ao menos formalmente. Sob o regime do direito processual civil, o juiz é responsável por decidir um caso de acordo com a verdade dos fatos. O juiz decide ambos o fato e o direito, porque não há júri, ou algo parecido. Supõe-se que a verdade dos fatos será revelada por elementos de prova pertinentes. Sob a civil law, donde resulta que o juiz é responsável por suscitar provas relevantes. As partes em litígio de direito civil são representadas por advogados, e os defensores estão habilitados e obrigados a ajudar os seus clientes na apresentação de suas respectivas versões do caso. No entanto, em princípio, a função dos defensores é auxiliar o juiz no cumprimento da responsabilidade judicial, e não, como na common law, o juiz ser responsável apenas em termos das responsabilidades de representação dos defensores anteriormente exercidas. No conceito de direito civil, os advogados supostamente devem fornecer comentários e sugestões para o juiz, com uma deferência que varia de uma jurisdição de civil law para outra. Mas pelo menos em teoria eles não têm poder de iniciativa depois de terem apresentado as reivindicações e defesas nos autos, exceto com o consentimento do juiz." 
Entretanto, é de se observar no sistema da common law que grande parte dos casos em que se adota o sistema do "pré-trial discovery", "uma das partes não está interessada em resolver seu litígio, ou de solvê-lo por boa-fé, aplicando, dessa forma, subterfúgios e ardis para obter vantagens de forma ilícita ou imoral da outra parte." (CARVALHO FILHO, 2011). Na mesma linha, no sistema da civil law (e aqui adentrando-se no sistema brasileiro), apesar de se utilizar outros procedimentos para resolver o litígio, não está imune a celeuma dos excessos e desvirtuamentos do objetivo do processo.

Quanto ao sistema da civil law, Michele Taruffo, realizando um comparativo com a common law afirma:

(...) an adjudication in the civil law system proceeds according to an entirely different logic. In that system, the central figure, around whose function the task of the advocates center, is not the jury, but the judge. The central task in civil law adjudication is for the judge to identify the legal and factual issues involved and to decide them correctly. Also, and of equal practical importance, the judge is a permanent official who can adjourn court sessions to later dates as convenient. The logic of inquiry in that framework is to subdivide a case issue by issue, or by clusters of issue, considering both facts and law as to each issue. Concerning any such issue or cluster of issues, law and facts can be considered together because there is no jury to share in the decisional process. The function of preview for the parties can be accomplished by receiving items of evidence on the basis of the court's making a provisional or tentative appraisal of their significance and conducting further ad deeper inquiry only as necessary. The necessity for such further inquiry will be signaled by the party against whom the evidence was received. Evidence received on a tentative bases is taken as truth if there is no negative signal from the opposing party, but, if there is such a signal, the evidence remains open for disputation or discount at a subsequent session of the court. In contrast, the logic of a jury trial is to subdivide the case into issues of law, regardless of the relationship of fact are further subdivided into a preview (discovery) and a plenary stage of presentation (the trial).(TARUFFO, Michele, 1998, p. 1021). ${ }^{8}$

8 Tradução livre: (...) um julgamento no sistema da civil law procede de acordo com uma lógica completamente diferente. Nesse sistema, a figura central, em torno de cuja função a tarefa dos advogados é focada, não é o júri, mas o juiz. A tarefa central na prestação jurisdicional da civil law é a de que o juiz identifique as questões legais e factuais envolvidas e decida corretamente. Além disso, e de igual importância prática, o juiz é um funcionário permanente, que pode adiar sessões do tribunal para datas posteriores da forma que achar conveniente. A lógica da investigação nesse quadro é subdividir um caso questão por questão, ou por grupos de questões, considerando ambos os fatos e o direito a cada edição. Concernente a qualquer questão ou conjunto de questões, direito e fatos podem ser considerados em conjunto, porque há júri para participação no processo decisório. A função da previsão para as partes pode ser realizada através da recepção de elementos de prova com base no tribunal estar fazendo uma avaliação provisória ou preliminar de seu significado e realização de inquérito mais profundo apenas quando necessário. A necessidade de tal inquérito mais adicional será sinalizada pela parte contra quem a prova foi recebida. Provas recebidas em uma base provisória são tidas como verdade, se não houver nenhum sinal negativo da parte contrária, mas, se houver tal sinal, as provas para continuam abertas para disputa ou para desconto em uma próxima sessão de tribunal. Em contrapartida, a lógica de um julgamento com júri é subdividir o processo em questões do direito, independentemente da relação de fato se subdividir em uma prévia (Descoberta) e uma fase plenária de apresentação (o julgamento). 
Com efeito, demonstrado os traços característicos do instituto da discovery inserido na Common Law, e verificado que neste sistema o juiz atua com demasiada neutralidade processual, principalmente quanto ao impulso oficial para "buscar a verdade", busca-se adotar no sistema brasileiro, diferentemente daquele sistema, a "convivência de poderes de impulso similares, outorgados às partes e ao juiz" (ASSIS, 2011). no fito de induzir "à criação de uma comunidade de trabalho, na qual o órgão judiciário pode e deve atuar ao lado das partes(...)". (ASSIS, 2011). Assim, prima-se pelo processo cooperativo como modelo de processo do estado constitucional brasileiro, conforme se estudará a seguir.

\section{O Processo CoOperativo, como modelo de Processo DO ESTADO CONSTITUCIONAL: DIREITO FUNDAMENTAL A UMA PRESTAÇÃO DE TUTELA JURISDICIONAL CÉLERE E EFETIVA}

$\mathrm{O}$ formalismo processual, no que se refere ao papel reservado aos juízes e às partes, se divide e se distingue, acompanhando a organização social de seu tempo, em três modelos: o modelo paritário, o modelo hierárquico e o modelo colaborativo.

O modelo paritário de organização social se caracteriza pela nítida "indistinção entre a esfera política, a sociedade civil e o indivíduo, de modo que o juiz (presentante do Estado, como diríamos em linguagem corrente) se encontra no mesmo nível das partes" (MITIDIERO, 2009, p. 64). Destarte, podem-se exemplificar as experiências políticas grega e ítalo-medieval ${ }^{9}$ como relações em que pairava a isonomia entre o juiz e as partes, daí a atuação paritária do juiz. (MITIDIERO, 2009, p. 64)

\footnotetext{
9 "Tirante as concepções da Baixa Idade Média, em que o direito não ocupava um posto autônomo, restando açambarcado nos domínios da ética, o direito a partir da fundação do studium civile passa a ser identificado com tudo aquilo que consta do Corpus Iuris Civilis, que então vem ocupar local de destaque na cultura jurídica européia. Com efeito, os legistas medievais vislumbravam no Corpus romano a própria ratio scripta, o que levou o pensamento jurídico a comportar-se essencialmente como um pensamento orientado à interpretação de textos. (...). Pensa-se o direito com referencial à justiça, seu substrato ético, mas justiça já aí entendida como lex, como registra a doutrina. Sendo o direito medieval baseado na autoridade dos textos romanos, cujo fundamento de legitimidade mesmo pendulou no tempo, o jurista o trabalhava como um enunciado textual do qual, mercê da exegese e da argumentação, seria possível obter todos os critérios para a prática jurídica. A partir dos textos passava-se ao caso, que polarizava a atenção dos juristas no cenário judiciário. E aqui temos um ponto de relevo. Ao contrário do que sucedeu no direito moderno, cujos padrões de racionalidade convocados para auxiliarem os juristas mais se afeiçoavam à lógica teórica, a racionalidade do medievo identificava-se com uma racionalidade prática, buscando conceber o direito como um problema concreto que o jurista tem de resolver visando ao consenso, ao fim e ao cabo, critério de verdade e justiça no ambiente medieval. Assume fundamental relevância, nesse especial, o diálogo entre as pessoas que participavam do processo, justamente aqueles que se dedicavam à resolução do problema em que se consubstanciava o próprio ius. A solução da problemática jurídica não se oferecia como a obra de uma razão individual, sendo, antes, o resultado do colóquio judiciário. Não é à toa, pois, que o juízo era entendido como um ato de três pessoas, como referiam incessantemente os glosadores ("iudicium est actus ad minus trium personarum: actoris, rei, iudicis")."(MITIDIERO, 2009, p. 78-80).
} 
Por outra banda, o modelo hierárquico "pressupõe-se uma nítida distinção entre indivíduo, sociedade e Estado (ou Império), estabelecendo-se uma relação vertical de poder entre esse e aquele." (MITIDIERO, 2009, p. 66) Observa-se, portanto, que o juiz se posta acima das partes, caracterizando a assimetria do modelo. "Duas experiências históricas podem, de um modo geral, ilustrá-lo: o processo civil romano da cognitio extra ordinem e o processo civil do Estado Moderno ${ }^{10}$ (especificamente, o processus prussiano do século XVIII)." (MITIDIERO, 2009, p. 66).

Quanto ao modelo cooperativo, Daniel Francisco Mitidiero explana com maestria sobre o tema:

O modelo cooperativo, de seu turno, funda-se em outras bases. Se é certo que, nessa quadra, permanece a moderna distinção entre Estado, sociedade e indivíduo, não menos certo se mostra que o modelo cooperativo organiza as relações entre esses três elementos de maneira bastante diferente daquela, por exemplo, oferecida pelo Estado Nacional Moderno. A Constituição, que tem como referencial uma sociedade cooperativa, conforma o Estado como um Estado Constitucional, cujas duas grandes virtudes estão na sua submissão ao Direito e na participação social na sua gestão (o Estado Constitucional, assim, é necessariamente um Estado de Direito Democrático ou, como prefere a nossa Constituição, um "Estado Democrático de Direito", art. $1^{\circ}$, caput). Essa conformação, no que agora interessa, funda o Estado na "dignidade da pessoa humana" (como está, aliás, igualmente em nossa Constituição, art. $1^{\circ}$, III), objetivando "construir uma sociedade livre, justa e solidária" (consoante também consta de nossa Constituição, art. $3^{\circ}$, I). Daí a razão pela qual a sociedade contemporânea pode ser considerada ela mesma um empreendimento de cooperação entre os seus membros em vista da obtenção de proveito mútuo. Não por acaso, considerada doutrina já alude mesmo à existência de um verdadeiro "Estado Constitucional Cooperativo". Essas características imprimidas pela sociedade no Estado através da Constituição evidentemente acabam repercutindo na posição ocupada pelo juiz no processo. O juiz do processo cooperativo é um juiz isonômico na condução do processo e assimétrico no quando da decisão das questões processuais e materiais da causa. Desempenha

10 "De outro lado, a maneira como se dá a organização interna do processo na Idade Moderna é marcada por uma grave fratura em relação ao modelo isonômico medieval, bem servindo para ilustrar a caracterização do modelo assimétrico de processo. À passagem do ordo iudiciarius isonômico ao processus assimétrico, com efeito, confluíram elementos culturais, políticos e ideológicos que imprimiram uma nova feição ao jurídico, tendo imediato reflexo na concepção do processo civil. Consoante já se anotou, o processo não é infenso à cultura, restando antes profundamente influenciado por essa. O clima cultural da Europa do século XVII condicionou todo direito posterior, propiciando a radical transformação do iudicium em processus, como agudamente observa a doutrina. Se o direito medieval servia-se da dialética, campo do discurso argumentativo e do provável, o direito moderno alçou mão, para estruturação da "ciência" jurídica, da lógica apoditíca, que trabalha com a demonstração e com a verdade. 0 direito deixa de ser um problema que o jurista tem de resolver trabalhando em um esquema sujeito-sujeito para ser um objeto que o operador do direito tem de conhecer, compreendido numa relação sujeito-objeto: passa-se de uma racionalidade prática à racionalidade teórica, notadamente na sua expressão de positivismo jurídico, ocorrendo uma verdadeira geometrização do jurídico, já que o protótipo do conhecimento, dentro desse peculiar ambiente, passa a ser a matemática. $O$ deslocamento do substrato lógico com que trabalhavam os juristas medievais e modernos não passou despercebido da doutrina, que bem surpreendeu o movimento que levou os juristas da dialética aristotélica, de usança geral entre os medievais, à lógica de Pierre de la Ramée, também conhecido como Petrus Ramus, que conduziu o discurso dos modernos, instalando o paradigma racionalista dentro do direito processual civil." (MITIDIERO, 2009, p. 83-84). 
duplo papel, pois, ocupa dupla posição: paritário no diálogo, assimétrico na decisão. Visa-se a alcançar, com isso, um "ponto de equilíbrio" na organização do formalismo processual, conformando-o como uma verdadeira "comunidade de trabalho" entre as pessoas do juízo. A cooperação converte-se em uma prioridade no processo.(MITIDIERO, 2009, p.71-73).

Com efeito, no modelo colaborativo, percebe-se a isonomia entre o juiz e as partes quando do deslinde do processo, por meio do diálogo judicial com ênfase no princípio do contraditório ${ }^{11}$. Destarte, o magistrado participa ativamente do processo juntamente com as partes, possibilitando que influenciem suas possíveis decisões.

Um elemento essencial do modelo cooperativo de processo está na figura do juiz, pois, informado pelo formalismo-valorativo, é irreversível que exerça uma posição mais diretiva, envolvida e ativista. Portanto, o Estado-juiz no terreno probatório se vale de iniciativa ex officio para o regular deslinde do feito, sempre visando a uma decisão justa e não àquela pautada apenas pela legalidade (própria da cultura jurídica francesa individualista e privatista do século XIX). (MITIDIERO, 2009, p. 99-100)

Ao passo, completa Daniel Francisco Mitidiero:

(...)A comunhão de trabalho resta evidenciada com a iniciativa oficial em tema de prova na medida em que o seu resultado deve ser, necessariamente, submetido ao crivo das partes, possibilitando-lhes influir sobre o valor probante a ser outorgado pelo magistrado. Não há que se falar, ademais, em quebra da imparcialidade e da independência judiciais por obra da possibilidade de instrução por iniciativa oficial, como o ambiente social do modelo isonômico chegava a sugerir, porquanto imparcialidade e neutralidade são conceitos que não se confundem. Juiz ativo é o contrário de juiz neutro; um e outro, todavia, podem ser imparciais. A valoração da prova no processo cooperativo, de postremeiro, não se liga, de regra, a vínculos legais apriorísticos, sendo nesse sentido considerada livre. Todo juízo de valor sobre a prova, contudo, tem de ser absolutamente motivado. É, aliás, como consta do art. 131 do nosso Código de Processo Civil, e como exige a doutrina italiana ao interpretar o art. 116 do Codice di Procedura Civile (MITIDIERO, 2009, p. 99-100).

O valor participação, ilustrado normativamente no contraditório (conforme se estudará alhures), é figura essencial do Estado Constitucional e democrático. Portanto, "a condução do processo é isonômica" (MITIDIERO, 2009, p. 76). Por outro lado, a juridicidade no processo é revelada quando das decisões do juiz, "que devem ser necessariamente justas e dimensionadas na perspectiva dos direitos fundamentais (materiais e processuais)" (MITIDIERO, 2009, p. 76-77). Destarte, sem olvidar-se do plano democrático, tais decisões são postas assimetricamente pelo Estado-juiz, revelando, por definição, assim, a atuação jurisdicional decisória como assimétrica. (MITIDIERO, 2009, p. 76-77)

11 Toda a condução do processo dá-se com a observância, inclusive com relação ao próprio juiz, do contraditório. A propósito, o art. 16 do Nouveau Code de Procédure Civile é paradigmático a respeito do tema, assim como o art. 266 do Código de Processo Civil português e o $§ 139$ da Zivilprozessordenung alemã.” (MITIDIERO, 2009, p. 73-74). 


\section{O citado autor assevera:}

Da combinação dessas duas faces do Estado Constitucional e de suas manifestações no tecido processual surge o modelo cooperativo de processo, calcado na participação e no diálogo que devem pautar os vínculos entre as partes e o juiz. Esse modelo de processo pressupõe, além de determinadas condições sociais, também certas opções lógicas e éticas para sua cabal conformação. (MITIDIERO, 2009, p. 77).

\section{O modelo cooperativo é diferente daquele visto no Estado Moderno, o qual} influenciou em demasiado o Código de Processo Civil de 1973, principalmente quanto à estruturação do formalismo processual. Assim, em atenção ao princípio fundamental ao contraditório ${ }^{12}$, houve a incrementação nos "poderes das partes a respeito da valoração do material jurídico da causa" (MITIDIERO, 2009, p. 91).

\section{Completa Mitidiero:}

Essa proposição acaba por implicar nova organização do formalismo processual, forçando a uma melhor distribuição das posições jurídicas das partes e do juízo no processo, de modo a tornar-lhe mais cooperativo e menos rígido para uma ótima consecução da justiça no caso concreto, finalidade última do processo civil no marco teórico do formalismo-valorativo. No que tange especificamente ao problema da aplicação do direito no processo, cumpre submeter a uma revisão crítica os brocardos Da mihi factum, dado tibi ius e Iura novit curia, próprios de um processo assimétrico, alimentado por uma lógica apodítico-mecanicista acerca do que é o direito. A três, pressupondo o direito ao contraditório como direito a participar do processo, a influir positivamente sobre o convencimento judicial, tem-se entendido que as partes têm o direito de se pronunciar também sobre a valoração jurídica da causa, tendo o juiz o dever de submeter ao diálogo a sua visão jurídica das questões postas em juízo, mesmo sobre aquelas questões que deve conhecer de ofício. Objetiva-se, assim, evitar decisões que apanhem de surpresa as partes, havendo aí evidente concretização da cooperação no processo pela mão do dever de consulta às partes que toca ao órgão jurisdicional, inerente à construção de um processo civil pautado pela colaboração. (MITIDIERO, 2009, p. 92-94).

\section{Sérgio Gilberto Porto, na mesma linha, complementa:}

É com esse espírito que a combinação das atividades do autor, do demandado e do juiz assumirá a estrutura ínsita do conceito de cooperação. Se cada um desses sujeitos trabalhar debruçado sobre a mesma matéria fática e jurídica, cada qual poderá trazer valiosas conclusões para iluminar o thema decidendum. $O$ processo transforma-se em um laboratório, no qual todas as partes são convidadas a trabalhar, tal como cientistas fossem. (...) Essa seria uma manifestação positiva do princípio da colaboração. A investigação solitária do órgão judicial, nos dias atuais, mostra-se inadequada(...) Quando se fala em colaboração entra as partes, admite-se que é justamente pela soma de seus esforços que o órgão judicial encontrará condições plenas para

12 “A jurisprudência do Bundesverfassungsgericht a propósito da Anspruch auf rechtliches Gehör (art. 103, Constituição alemã) não deixa dúvidas, consoante informa a doutrina, a respeito da configuração do direito ao contraditório como sendo um direito a influenciar efetivamente o juízo sobre as questões da causa (fácticas, jurídicas e mistas, materiais e processuais), tendo à base uma compreensão problemática do direito. A jurisprudência de nosso Supremo Tribunal Federal inclina-se atualmente nesse mesmo sentido. Contraditório, pois, entendido em "senso forte" (...) (MITIDIERO, 2009, p. 91). 
a aplicação do direito. Em outras palavras, é da soma de comportamentos parciais (tese, esposada pela pretensão + antítese, representada pela defesa) que o processo alcançará a justa síntese. Este, então, é o método de trabalho preconizado pela adoção do princípio do contraditório. (PORTO, 2009, p. 54-55).

Finalmente, conclui-se que o modelo cooperativo ${ }^{13}$, sobretudo, molda-se pela Carta Magna e, em vista disto, nos direitos fundamentais. Estes, externados e implícitos, fundamentalmente, mediante princípios constitucionais.

\section{O DEVER FUNDAMENTAL DO EXECUTADO DE NOMEAR BENS PASSÍVEIS DE PENHORA E O INSTITUTO DA CONTEMPT OF COURT}

$\mathrm{Na}$ medida em que a realidade social se altera, as reformas legislativas, em regra, acompanham tais modificações para evitar-se a defasagem normativa e para serem alcançados os anseios legítimos da sociedade contemporânea e jurisdicionada. (CARPENA, 2011)

Com efeito, a Lei n. ${ }^{\circ} 11.382$, de 07 de dezembro de 2006, atendendo a esse propósito, trouxe novos mecanismos instrumentais para permitir uma melhor efetividade da prestação jurisdicional executiva.

Márcio Louzada Carpena advoga que:

Na perspectiva da nova disposição legal, vários pontos chamam a atenção, sobressaindo-se, contudo, na nossa concepção, aquele que passa, expressa e indubitavelmente, a exigir uma conduta de mais comprometimento e de colaboração do réu, então executado, para com a efetividade da prestação jurisdicional e celeridade do desfecho da lide, fixando, por outro lado, meios de reprimenda às atitudes que se mostrem contrárias a tais interesses. Com efeito, a nova norma segue a orientação ideológica, já disposta anteriormente em outras leis que ultimamente alteraram o processo de conhecimento no CPC, de exigir um comportamento leal e ético das partes, principalmente do demandado, coibindo, ainda que pontualmente, atos que importem procrastinação ou alongamento desarrazoado ou indevido do tempo do processo executivo, impedindo que ele se torne, na prática, instrumento de tortura da parte que tem crédito a receber e de desprestígio da própria atividade jurisdicional estatal. (CARPENA, 2011).

Assim, devem-se inibir os comportamentos que ferem a devida tempestividade da lide executória. Neste sentido, deve-se rechaçar "a conduta desequilibrada ou abusiva

13 “Outrossim, podem ser apontados como grandes vetores orientadores do princípio da cooperação: (a) a mudança de mentalidade das pessoas que participam do processo; (b) o incentivo à boa-fé e lealdade do órgão judicial, das partes e seus representantes, e de todos os demais participantes do processo (escrivão, serventuário, perito, assistente técnico, testemunhas etc.): o processo não é uma luta ou um duelo, que se possa vencer a qualquer custo; (c) o combate ao formalismo excessivo; (d) o fortalecimento dos poderes das partes, dentro de uma visão não autoritária do papel do juiz e mais contemporânea quanto à divisão do trabalho entre o órgão judicial e as partes; (e) a necessidade de permanente diálogo entre as partes e entre estas e o juiz (reprovável, portanto, que este se negue a receber advogados, fator, aliás, que atua como forte elemento de deslegitimação do Poder Judiciário perante a sociedade civil)" (OLIVEIRA, 2010, p. 41). 
de uma das partes, ao longo de um processo, no intuito de protelar a efetivação da prestação jurisdicional”. (CARPENA, 2011)

Dessa forma, afastando-se os comportamentos descomprometidos e não colaborativos com o desenrolar da demanda judicial, estar-se-á primando pela defesa das disposições da Constituição Federal e, principalmente, no caso, pela razoável duração do processo e dos meios que garantem a celeridade de sua tramitação (inciso LXXVII do artigo $5^{\circ}$ ).

Por outra banda, no tocante ao dever de cooperação do executado à indicação de bens passíveis de penhora, Márcio Louzada Carpena completa:

Na Lei 11.382, a idéia de exigência de colaboração do demandado para com o desenvolvimento escorreito da tutela jurisdicional, e até mesmo para com a satisfação do direito da parte adversa, então exeqüente, extrai-se claramente a partir de vários dispositivos, tais como e entre outros: do art. 740, parágrafo único, quando passa a impor multa para o caso de apresentação de defesa - embargos - com intuito tido por procrastinatório; do art. 745-A, parágrafo $2^{\circ}$, quando comina, no caso de inadimplência de pedido de pagamento parcelado, multa sobre o valor das prestações não pagas, sem prejuízo de vedação à oposição de embargos; do art. 746, parágrafo $3^{\circ}$, quando impõe multa, caso os embargos à arrematação forem declarados manifestamente protelatórios. Com efeito, todos esses dispositivos trazem sanções passíveis de serem impostas ao executado em razão de atitudes (ações) contrárias à conduta de cooperação esperada e que, de fato, causam embaraços ao normal desenvolvimento da demanda e prejudicam a efetividade da tutela jurisdicional. (CARPENA, 2011).

Importante alertar sobre a redação conferida aos artigos 652 , parágrafo $3^{\circ} \mathrm{e}$ 656, parágrafo $1^{\circ}$, para referendar a obrigação do executado em colaborar com a seleção de bens a serem constritos, sob pena de sanção ${ }^{14}$.

Destarte, pode-se observar na lei claramente:

o dever de cooperação do executado em um dos momentos mais delicados da execução, qual seja, a localização de bens do demandado para submissão ao procedimento expropriatório. (CARPENA, 2011).

Ao passo, adentrando-se na análise das sanções impostas ao executado, no caso da não colaboração na lide executiva, parte-se do pressuposto que a multa fixada pelo juiz deve refletir as peculiaridades do caso concreto. Assim, cabe ressaltar, quanto à ofensa ao Judiciário, que "há duas espécies de multa: a condicional e a definitiva. No primeiro caso, exibirá nítido caráter coercitivo, induzindo o destinatário ao cumprimento da ordem judicial; no segundo, a nota repressiva predomina.” (ASSIS, 2003, p. 22)

${ }^{14}$ A redação legal consigna que o juiz "poderá, de ofício ou a requerimento do exeqüente, determinar, a qualquer tempo, a intimação do executado para indicar bens passíveis de penhora", bem como determina que é "dever do executado (art. 600), no prazo fixado pelo juiz, indicar onde se encontram os bens sujeitos à execução, exibir a prova de sua propriedade e, se for o caso, certidão negativa de ônus, bem como abster-se de qualquer atitude que dificulte ou embarace a realização da penhora (art. 14, parágrafo único)". 
A inclusão do inciso V e do parágrafo único no art. 14, por meio da Lei 10.358, de 17.12.2001, demonstra claramente a influencia do instituto do contempt opf court do direito anglo-saxão.

Na mesma senda, Araken de Assis, quanto à influência mencionada, inclui a modificação do art. 601 do CPC, através da Lei n. ${ }^{\circ}$ 8.953, de 13.12.94. (ASSIS, 2003, p. 18)

Observa-se, portanto, que determinando o magistrado que o executado apresente os bens, no prazo de 5 (cinco) dias, passíveis de penhora e negando-se em fazê-lo - ou criando quaisquer embaraços à determinação judicial -, incidirá contra o jurisdicionado recalcitrante (executado), as seguintes sanções, a saber: (a) multa por afronta à dignidade da justiça, prevista no art. 600, inc. IV, combinado com art. 601, ambos do CPC, de até $20 \%$ (vinte por cento) sobre o valor exequendo; e, (b) multa por ato atentatório à dignidade da jurisdição, prevista no art. 14, parágrafo único, CPC, de até 20\% (vinte por cento) sobre o valor da causa.

Assim, ao tratar do art. 601, o qual prevê a sanção ao devedor desobediente de até vinte por cento do valor da execução, o autor supramencionado, ainda, certifica que "por sem dúvida, se cuida de pena por desacato, similar àquela do contempt of court, sob forma definitiva." (ASSIS, 2003, p. 28)

Com efeito, Luiz Guilherme Marinoni assevera a respeito da multa para compelir o devedor a indicar bens à penhora:

Acontece que tal multa é vista como pena, isto é, como sanção pecuniária contra o devedor que comete ato atentatório à dignidade da justiça. Nesse sentido, ela somente poderia ser considerada após a prática da conduta lesiva à "dignidade da justiça". Não obstante, até porque o leigo não conhece as regras processuais e, muitas vezes, não é informado pelo seu advogado sobre as suas conseqüências, tem o exeqüente, no caso de não pagamento do valor da condenação, não só a oportunidade de requerer a expedição de mandado de penhora e avaliação (art. 475-J, caput, parte final, CPC), mas também o direito de pedir ao juiz a intimação do devedor para indicar bens à penhora, na forma dos arts. 600, IV e 655 do CPC, sob pena de multa de até $20 \%$ do valor do débito atualizado. Desta forma, confere-se à multa do art. 601 significado muito mais importante. Além de a multa passar a ter a função de forçar ao cumprimento, esta jamais será imposta sem que o executado tenha real e efetivo conhecimento das conseqüências da não observância dos arts. 600, IV e 655, I, do CPC. (MARINONI, 2010, p. 463-464).

Araken de Assis afirma:

Por outro lado, o art. 14, V, e parágrafo único, da Lei 10.358, de 27.12.01, generalizou a sanção por contempt of court. De fato, previu a imposição de multa no caso de descumprimento dos provimentos mandamentais, de modo similar ao que acontece com a injunction norteamericana, sancionando, além disto, a criação de embaraços à efetivação dos provimentos judiciais, de natureza antecipatória ou final. Podem ser sujeitos passivos da multa as partes e todos aqueles que de qualquer forma participam do processo (art. 14, caput). Ficam alheios à punição, porém, como é da tradição do direito pátrio, os advogados, cujo controle disciplinar 
incumbe à Ordem dos Advogados, inferindo-se tal exceção da cláusula inicial do parágrafo único do art. 14. (ASSIS, 2003, p. 29).

\section{Ensina Eduardo Talamini:}

Por fim, cabe menção a determinados deveres de fazer e de não fazer que podem surgir no curso de um processo e estão instrumentalmente vinculados à efetivação da tutela relativa a deveres de entregar ou pagar. Pense-se no dever que tem o executado de indicar onde se encontram os bens sujeitos à execução (art. 600, IV) ou no dever de permitir o acesso dos auxiliares do juízo ao local em que se encontram os bens sujeitos à efetivação da tutela jurisdicional (art. 14, V). Tais deveres instrumentais de fazer e de não fazer têm natureza processual. Recaem, em última instância, no dever de colaborar com o funcionamento da justiça e não praticar atos que atentem contra sua dignidade (e, por isso, não vigoram apenas dentro do processo executivo do Livro II). A violação desses deveres processuais é sancionada com as penas gerais atinentes à litigância de má-fé, com as penas específicas dos arts. 14, par. ún. (aplicável a qualquer tipo de processo) e 601 (quando a violação ocorre no processo executivo) e, em certos casos, pode dar ensejo a indenização civil e punição criminal. (TALAMINI, 2003, p. 162-163).

Com efeito, cabe não olvidar outra singela diferença entre a multa do art. 14 e as astreintes.

"O juiz fixará a multa mencionada no art. 14 após o descumprimento da decisão judicial, enquanto no caso dos arts. 461 e 461-A a multa é fixada antes, para compelir a parte a cumprir a decisão." (WAMBIER, 2005, p. 236).

\section{A "pena" das astreintes deve ser prévia.}

"O juiz determina a sanção para o futuro (para que a parte não venha a descumprir a ordem), não para o passado (sancionando um comportamento já realizado), pois não se trata de tutela de ressarcimento, mas sim de inibição". (CARPENA, 2005, p. 203).

Portanto, todos aqueles que participam do processo e criam embaraços à efetivação de provimentos judiciais podem ser enquadrados no art. 14, parágrafo único, do Código Processual Civil, respondendo, independentemente de outras sanções (criminais, civis e processuais), por multa a ser fixada em conformidade com a extensão da conduta desrespeitosa praticada, atentando-se ao limite máximo legal, qual seja, 20\% (vinte por cento) do valor da causa. (CARPENA, 2005, p. 199) E aqui, portanto, o executado pode ser enquadrado por não apresentar bens passíveis da constrição judicial.

Veja-se que se pode denominar como pena a sanção retributiva negativa (punitiva) voltada ao infrator da norma, na medida em que se traz um prejuízo a este. Almeja-se, aqui, a desaprovação da conduta ilícita praticada e não o resultado prático equivalente em razão do descumprimento do preceito normativo, tampouco imprimir pressão psicológica sobre a vontade do jurisdicionado. Notório que a sanção punitiva está presente em outros ramos do direito, como nas punições criminais, administrativas, fiscais etc. 
"No processo civil, têm caráter retributivo as multas previstas nos arts. 14, par. ún. e 601. Portanto, também há sanção punitiva civil.” (TALAMINI, 2003, p. 180).

Dentro da ideia de cooperação, principalmente no tocante à fase executiva, importante realçar o instituto do contempt of court, o qual na lúcida visão de Araken de Assis:

Tutela o exercício da atividade jurisdicional, nos países da common law, e existe desde os tempos da lei da terra. Cumpre advertir que a expressão "common law", ou direito comum à toda comunidade, não merece tratamento uniforme na América e no Reino Unido. E isso, porque a América se organizou sob a forma de Federação, competindo aos Estados legislar sobre direito material e processual. Conquanto subordinado esse direito estadual à Constituição, a rigor inexiste uma "lei comum" na América. Como quer que seja, o poder de contempt of court, reconhecido aos órgãos judiciários, nesses países, consiste no meio de coagir à cooperação, ainda que de modo indireto, através da aplicação de sanções às pessoas sujeitas à jurisdição. (ASSIS, 2003, p. 18-19)

Por oportuno, importante trazer à baila a definição de Cristina Reindolff da Motta ao instituto em epígrafe:

Contempt of court consiste no comportamento de alguém ignorar a autoridade do órgão judiciário. É ofensa à corte de justiça ou à pessoa que recebeu a delegação do poder soberano de julgar. É desobediência à corte, através de franca oposição ou de desdenho à autoridade, ou dignidade, ou de justiça da corte. Freqüentemente, consiste em uma das partes fazer o que entender mais conveniente para si, ou em não fazer o que lhe foi ordenado, comandado ou requerido através de um decreto, ordem ou processo. (MOTTA, 2002, p. 54)

Portanto, a influência do sistema da Commn Law, advindo dos Estados Unidos da América, acarretou mudanças em vários ordenamentos jurídicos pelo mundo. No Brasil não foi diferente, o legislador brasileiro, principalmente na última década, importou alguns institutos norte-americanos para o sistema nacional, dentre eles: o contempt of court. A inserção de inc. V e parágrafo único ao art. 14, obra da Lei n. ${ }^{0} 10.358$, de 17.12.2001, demonstra o referido espelhamento.

\section{Márcio Louzada Carpena assevera:}

A exposição de motivos do Projeto (n. $\left.{ }^{\circ} 3.475 / 00\right)$ que deu origem à atual redação do art. 14 do CPC, aliás, bem ilustra o desiderato do legislador em robustecer a ética no processo civil, muito especialmente a partir da exigência de conduta leal e proba que deve nortear a atuação da dialética, impondo a cooperação como um dever (obrigação) de todos os cidadãos, partes ou não no feito. No diapasão de reprimir o desrespeito em benefício do prestígio e imperatividade da Justiça se mostra, então, patente a importância de tal dispositivo legal. (CARPENA, 2005, p. 200).

Diga-se, contudo, que a ideia de contempt of court não fica adstrita somente ao referido artigo. O consagrado processualista Araken de Assis define o instituto como "a ofensa ao órgão judiciário ou à pessoa do juiz, que recebeu o poder de julgar do povo, 
comportando-se a parte conforme suas conveniências, sem respeitar a ordem emanada da autoridade judicial." (ASSIS, 2003, p. 20)

Outrossim, Edward Dangel entende que o contempt of court se trata da desobediência das ordens emanadas pelo juiz ou até mesmo pela pura e simples desobediência legal. Da mesma maneira, tal desobediência se estende até a interrupção, através do mau comportamento, do deslinde "normal" dos procedimentos, maculando a imagem do Judiciário e do Legislativo. (DANGEL, 1939, p. 2)

Conclui Luiz Antônio Miranda Amorim Silva que esse desígnio anglo-saxão engloba quaisquer das ofensas ao Judiciário. Atenta-se que os países que adotam a Common Law utilizam os mecanismos da prisão e da multa para encarar o contempt of court. Entretanto, no Brasil, diferentemente, lança-se mão, em princípio, do instrumento da multa para garantir o respeito ao Poder Judiciário, entendendo-se que a prisão ${ }^{15}$, nessa hipótese, negaria a Constituição. (SILVA, 2008, p. 157)

${ }^{15}$ Elucida Araken de Assis : "Evidentemente, a ameaça de prisão constitui meio de notória eficiência para induzir o destinatário da ordem, e às partes, em geral, ao cumprimento da ordem judicial. Qual é sua compatibilidade com o ordenamento brasileiro? (...) Assim, o art. 5. ${ }^{\circ}$, LXVII, somente autoriza a prisão, e a título excepcional, do devedor de alimentos e do depositário infiel. Apesar do campo de atuação restrito, o êxito do mecanismo parece indiscutível. A seu favor, o alimentário e o depositante depõem, com um suspiro de alívio e de gratidão; os juízes, de seu turno, guardam a melhor das impressões do seu uso, porque resolvem o problema de maneira rápida, atendendo o interesse básico de quem clama por alimentos. Ao propósito, o encantador realismo de experiente e sensível magistrado diagnosticou que, decretada a prisão "o dinheiro sempre aparece". (...) As armas do órgão judiciário brasileiro perante as atitudes desafiadoras das partes e outros figurantes do processo se cingem à aplicação de multas. Sanções dessa natureza não abalam alguém desprovido de patrimônio. (...)A prisão civil funda-se no inadimplemento imputável de dívida, e, não, no desatendimento à ordem judicial(...) Nada obstante, vencidas as resistências ideológicas, é possível introduzir a prisão por desacato à autoridade judiciária no ordenamento brasileiro? Em princípio, o crime de desobediência (art. 330 do CPB) equipara-se ao contempt of court criminal. Porém, distingue-se do seu modelo em ponto capital: não visa a induzir ao cumprimento, senão de modo indireto e longínquo, mas a reprimir a lesão a determinado bem jurídico. (...)É preciso ter em mente, neste delicado e controvertido assunto, o princípio estrita legalidade (art. $5 .^{\circ}$, XXXIX, da CF/88 e art. $1 .^{\circ}$ do CPB). Em matéria penal, diferentemente do que sucede nos domínios civis, pouco espaço há para conceitos jurídicos indeterminados e interpretações por analogia. Sob tal perspectiva rigorosa, o tipo penal do art. 330 do CPB não favorece, absolutamente, a introdução definitiva do contempt of court. Em primeiro lugar, o art. 330 do CPB (...) contemplando os crimes praticados por particulares contra a Administração Pública. Idêntica é a situação do crime de resistência (art. 329 do CPB). Em ambos os casos, o sujeito ativo do crime é apenas o particular, e o sujeito passivo a Administração. Somente através de forçada e artificial extensão, no fundo, se pode incluir a autoridade judiciária no âmbito da "Administração". (...) Ademais, servidor público somente pratica, por hipótese, o crime de desobediência, despindose da sua inerente condição;" (ASSIS, 2003, p. 31-33). O autor entende, outrossim, que quem não tem competência para cumprir às providências legais exigidas, tampouco pode ser condenado ao crime de desobediência. Assim, conclui que "Esta última exigência contrasta, claramente, com a indeterminada planície do art. 14, caput, do CPC, que põe sob o guante judicial as partes "e todos aqueles que de qualquer forma participam do processo." (...) Essas dificuldades técnicas revelam quão longe se encontra o direito pátrio de consagrar o contempt of court criminal. Na verdade, a sanção penal constitui ameaça longínqua, sujeitando-se a percalços na tipificação. (...) Exemplo de tutela penal precisa e clara se localiza na execução de alimentos. $O$ art. 21 da Lei 5.478/68 reformulou o art. 244 do CPB, tipificando a conduta do alimentante: de um lado, é crime deixar de "prover a subsistência" do alimentário; de outro, incorre em idêntica pena o alimentante que, solvente, "frustra ou ilide, de qualquer modo, inclusive por abandono injustificado de emprego ou função”, o pagamento dos alimentos.” (ASSIS, 2003, p. 33-35). 
Nessa senda, imprescindível a busca de mecanismos para dar ensejo ao respeito às decisões judiciais. "Tolerar procedimentos abusivos e desafiadores da Justiça é permitir a ruína da organização estatal". (CARPENA, 2005, p. 201) A oposição aos atos atentatórios às decisões judiciais deve ser contínua, "na medida em que se mostra fator contundente para proporcionar maior efetividade à atividade jurisdicional e apresenta inegável caráter pedagógico $^{16 "}$ (CARPENA, 2005, p. 201).

Especificamente a respeito do dever, pelo executado, da apresentação de bens a serem constritos, Márcio Louzada Carpena assevera:

Doravante, há a obrigação de o executado, mediante a discriminação de seu acervo patrimonial, colaborar com o exeqüente para que este escolha entre a gama de bens apresentada, aquele(s) que julgar mais adequado(s), observada a regra do art. 655 e as peculiaridades do caso em específico, a satisfazer o seu direito material. Por certo, de nada adiantaria fortalecer-se o dever de lealdade e colaboração do demandado no processo executivo, atrelando, por exemplo, a aplicação de multa de até $20 \%$ (vinte por cento) do valor em execução para o caso de propositura de embargos à execução manifestamente protelatórios (art. 740, parágrafo único, CPC), se não se combatesse o momento mais crítico e nevrálgico do processo expropriatório que é, com certeza, aquele em que se escolhe e se delimita o patrimônio do devedor a ser desapropriado, a fim de satisfazer-se o crédito do então demandante. (CARPENA, 2011)

Cabe não olvidar que, pela nova disposição legal, o executado não mais será intimado para solver sua dívida ou nomear bens a penhora quando da apresentação da execução. A nomeação de bens à penhora, agora, fica a cargo do exequente e poderá ser feita na própria petição inicial (art. 652, parágrafo $2^{\circ}, \mathrm{CPC}$ ). Entretanto, o exequente poderá requerer ao magistrado que determine a intimação do devedor para apresentação de bens passiveis de constrição, caso aquele não possa fazer. ${ }^{17}$ "Calha observar que a

${ }^{16}$ Verifica-se que o grau de culpa e dolo do agente será fator fundamental para a viabilidade da aplicação de uma sanção civil, e Maria Celina Bodin de Moraes (em que pese ser veemente em sua posição de negação da pena privativa de liberdade no ordenamento jurídico brasileiro) ensina que é imprescindível que: "se verifique, no caso concreto, se conduziu mal o agente ofensor, dando ocasião, assim, à elaboração de um juízo de proporcionalidade entre a conduta e o dano e, portanto, a individualização da sanção" (MORAES, 2003, p. 212).

${ }^{17}$ Aqui a questão merece atenção: o executado não deverá ser intimado para indicar bens à penhora, mas, sim, para indicar bens passíveis de penhora! A referência legal é absolutamente clara, e o propósito da norma é evidente: evitar a velha e conhecida situação, até então diariamente vivenciada nos foros, de o devedor fazer a nomeação de bens à penhora, porquanto a vida já demonstrou que tal circunstância, em regra, descamba para uma indicação de bens sem valia ou de difícil alienação, o que, por si só, como se disse, acaba por retardar o andamento do processo e conseqüentemente a satisfação do direito do credor. (...) Segundo nosso entendimento, a regra é no sentido de que o devedor deverá ser intimado para apresentar todo o seu patrimônio em juízo, a fim de que o credor possa selecionar um ou alguns bens sobre os quais recairá a constrição e posterior expropriação. Evidentemente que, a partir de tal momento, o processo deverá passar a correr em regime de segredo de justiça_, até mesmo para a preservação da "intimidade patrimonial" do devedor. Aliás, seguindo tal propósito, é importante notar que o juiz poderá determinar, inclusive, que o rol patrimonial do devedor não seja juntado aos autos, mas, sim, fique depositado em cartório até a finalização da lide.(...) Nesse diapasão, segundo nosso parecer, a regra é de apresentação de todo o acervo patrimonial. No entanto, se o caso concreto recomendar, a regra pode ser excepcionada. Evidentemente, se se verificar que a juntada de toda a extensão patrimonial do devedor não se mostrar proporcional ao caso dos 
referência legal introduzida, no sentido de exigir-se a cooperação do devedor na apresentação do patrimônio a ser constrito, representa um verdadeiro avanço." (CARPENA, 2011)

Importa abordar, antes de encerrarmos este estudo, as sanções pelo descumprimento injustificado do dever de indicação de bens pelo executado. A omissão injustificada do devedor quanto ao dever de indicação da localização dos bens sujeitos à execução $(C P C$, art. $600, I V)$ é contrária à lealdade e à boa-fé e retarda ou até mesmo compromete a entrega da prestação jurisdicional. Quanto a tal conduta lesiva, prevê o CPC em disposições aplicáveis ao Processo do Trabalho (exegese CLT, art. 889 e Lei 6.830/80, art. $1^{\text {o }}$ ):

Art. 14. São deveres das partes e de todos aqueles que de qualquer forma participam do processo: $\cdots$

V - CUMPRIR COM EXATIDÃO OS PROVIMENTOS MANDAMENTAIS E NÃO CRIAR EMBARAÇOS À EFETIVAÇÃO DE PROVIMENTOS JUDICIAIS, de natureza antecipatória ou final.

Parágrafo único. ... a violação do disposto no inciso $\mathrm{V}$ deste artigo CONSTITUI ATO ATENTATÓRIO AO EXERCÍCIO DA JURISDIÇÃO, podendo o juiz, sem prejuízo das sanções criminais, civis e processuais cabiveis, aplicar ao responsável MULTA em montante a ser fixado de acordo com a gravidade da conduta e não superior a vinte por cento do valor da causa; não sendo paga no prazo estabelecido, contado do trânsito em julgado da decisão final da causa, a multa será inscrita sempre como dívida ativa da União ou do Estado.

...

SEÇÃO II

DA RESPONSABILIDADE DAS PARTES POR DANO PROCESSUAL

Art. 16. Responde por perdas e danos aquele que pleitear de má-fé como autor, réu ou interveniente.

Art. 17. Reputa-se litigante de má-fé aquele que:

$\cdots$

IV - OPUSER RESISTENNCIA INJUSTIFICADA AO ANDAMENTO DO PROCESSO;

$V$ - PROCEDER DE MODO TEMERÁRIO EM QUALQUER INCIDENTE OU ATO DO PROCESSO;

autos, poderá o magistrado restringir a obrigação. Não há sentido em, por exemplo, determinar que uma grande empresa apresente todo o seu extenso patrimônio em uma execução cujo crédito executado seja de poucos salários mínimos. Pode e deve o julgador, neste caso, autorizar a apresentação parcial dos bens, desde que suficientes para garantir o juízo e satisfazer de maneira célere o eventual direito afirmado pela parte exequiente.(...) Nesses termos, previamente à intimação do executado para apresentar os bens a serem escolhidos para expropriação pelo credor, deverá o juiz definir qual é a extensão do inventário a ser apresentado, podendo, todavia, posteriormente, estendêlo mediante a análise da conduta do devedor e dos interesses do credor, segundo o que se referiu acima.Cumpre registrar, por oportuno, que a indicação por parte do executado de inventário falso, incompleto ou posteriormente verificado irreal (omissão de patrimônio), constitui comportamento temerário e absolutamente inaceitável, em legítimo abuso de direito. (...) A configuração de ato abusivo gera a incidência das sanções previstas nos arts. 17 e 18 do CPC, sem prejuízo da aplicação das multas consignadas nos arts. 14 e 601, do mesmo diploma legal. Não obstante tais regras acima, o fato é que o magistrado continuará autorizado a requisitar colaboração de terceiros para, ante a negativa do executado, descobrir qual é o seu patrimônio penhorável. $\mathrm{O}$ auxílio dos departamentos públicos e da própria Receita Federal, por certo, é medida que permanece útil e que se impõe em nome da eficiência da atividade jurisdicional. (CARPENA, 2011) 
$\cdots$

Art. 18. O juiz ou tribunal, de ofício ou a requerimento, condenará o litigante de má-fé a pagar multa não excedente a um por cento sobre o valor da causa e a indenizar a parte contrária dos prejuízos que esta sofreu, mais os honorários advocatícios e todas as despesas que efetuou.

$\cdots$

$\S 2^{\circ} \mathrm{O}$ valor da indenização será desde logo fixado pelo juiz, em quantia não superior a vinte por cento sobre o valor da causa, ou liquidado por arbitramento.

...

LIVRO II DO PROCESSO DE EXECUÇÃO - TÍTULO I - CAPÍTULO V DAS DISPOSIÇÕES GERAIS

Art. 598. Aplicam-se subsidiariamente à execução as disposições que regem o processo de conhecimento.

...

Art. 600. Considera-se atentatório à dignidade da Justiça o ato do executado que: $\ldots$

IV - INTIMADO, não indica ao juiz, EM 5 (CINCO) DIAS, quais são e onde se encontram os bens sujeitos à penhora E SEUS RESPECTIVOS VALORES...

Art. 601. Nos casos previstos no artigo anterior, o devedor incidirá em MULTA fixada pelo juiz, em montante não superior a vinte por cento do valor atualizado do débito em execução, sem prejuízo de outras sanções de natureza processual que reverterá EM PROVEITO DO CREDOR, exigível na própria execução.

Parágrafo único. Ojuiz relevará a pena, se o devedor se comprometer a não mais praticar qualquer dos atos definidos no artigo antecedente e der fiador idôneo, que responda ao credor pela dívida principal, juros, despesas e honorários advocatícios.

$\mathrm{O}$ ato atentatório à dignidade da Justiça por omissão, quanto à indicação do local dos bens prejudica tanto o Poder Judiciário quanto ao exequïente, deflagrando as seguintes multas cumulativas: (a) uma em prol da União ou do Estado, conforme o caso, nos termos do CPC, art. 14, parágrafo único; (b) outra, em prol do próprio exequente, nos termos do caput do art. 601 do CPC.

A destinação diversa das sanções do art. 14, parágrafo único e do art. 601, e a expressa previsão, em cada qual deles, de que elas não prejudicam outras da legislação processual, revelam que tais multas são cumulativas.

Já a multa por litigância de má-fé, prevista no caput do art. 18 do $\mathrm{CPC}$, não tem lugar em face da especialidade do art. 601 do CPC, para o caso de não cumprimento da determinação de indicação dos bens, ambas com o mesmo caráter sancionador (em percentuais superiores inclusive), obstando nova multa em prol do exequente que implicaria bis in idem.

Remanesce, porém, a possibilidade de cumulativamente às multas do CPC, art. 14, parágrafo único e art. 601, imputar ao executado o dever de indenizar, por perdas e danos, os prejuízos que o exequente sofreu (CPC, artigos 16 e 18, caput e $\S 2^{\circ}$ ).

Com efeito, ao passo que as multas têm caráter sancionador do ilícito praticado, a indenização prevista no art. 18 visa à reparação de prejuízos que o credor sofreu; as 
primeiras não excluem a segunda em razão da finalidade de cada qual, prevalecendo no caso a cumulação de medidas referendada inclusive tanto no art. 14, parágrafo único quanto no art. 601 do CPC.

A cumulação das multas com a indenização revela a subsistência de repressão ao executado mesmo na hipótese do parágrafo único do art. 601 do CPC, segundo o qual a pena será relevada se: (i) o devedor se comprometer a não mais praticar qualquer dos atos definidos no artigo antecedente; (ii) e der fiador idôneo, que responda ao credor pela dívida principal, juros, despesas e honorários advocatícios.

O perdão legal, satisfeitos os pressupostos, abrange apenas a multa do art. 601, caput, do CPC, sem prejuízo daquela do art. 14, parágrafo único e da indenização na forma dos artigos 16 e 18 do CPC (exegese do CPC, art. 601, parágrafo único).

Além disso, a isenção da pena do art. 601 só prevalece quando atendidos cumulativamente os pressupostos, assumindo o executado o compromisso de não reiterar a conduta e ofertando à execução meio alternativo/eficaz de sua satisfação mediante a obtenção de fiador idôneo (v.g., fiança bancária), motivando o favor legal.

A benesse não tem lugar nas hipóteses em que, embora assumindo o compromisso de não reiterar a conduta ilícita, o executado não oferta ao juízo meio alternativo e eficaz para a satisfação da execução (exegese CPC, art. 601, parágrafo único cc LICC, art. $\left.5^{\circ}\right)$.

\section{CONSIDERAÇÕES FINAIS}

Em virtude da legislação vigente, o executado deve atuar cônscio de que não se exime do dever de colaborar com o Judiciário (CPC, art. 339) e de que se encontra em estado de sujeição em relação ao exequente (princípio da preeminência do exequente CPC, art. 612).

A condução branda da execução relegou ao descrédito as ordens judiciais incutindo no executado a ideia de que ele não precisa cumpri-las, tampouco cooperar, tudo aos auspícios da frequente impunidade prejudicial à efetividade.

Tornou-se corriqueiro o decurso do prazo para pagamento sem qualquer providência pelo executado, o qual, ao invés de colaborar, geralmente atua de sorte a frustrar o cumprimento da decisão.

Os esforços legislativos das últimas reformas (todos dirigidos à efetividade da tutela jurisdicional) impõem aos juízes a adoção de hermenêutica mais rígida, intransigente em relação à injustificada mora/inadimplência no cumprimento das ordens judiciais, tendo sempre em mente que: (1) a dignidade da Justiça pressupõe a adoção de hermenêutica intransigente para com a inobservância aos deveres de cooperação e de indicação de bens, resgatando o respeito às ordens judiciais e assegurando a efetividade e celeridade da prestação jurisdicional; (2) no Processo Civil atual o mero decurso dos 
prazos para cumprimento da decisão ou para pagamento do valor em execução sem indicação de bens pelo devedor não são suficientes para a configuração de ato atentatório à dignidade da Justiça sendo necessária a intimação dele para tal fim; (3) a infração ao dever de indicação de bens configura ato atentatório à dignidade da Justiça, autorizando a cominação cumulativa de multas (em prol da União ou do Estado e do exequente) sem prejuízo de indenização nos termos dos artigos 16 e 18 do CPC; (4) o perdão assegurado no parágrafo único do art. 601 do CPC só exime o executado, satisfeitos os pressupostos, quanto à multa do caput do mesmo dispositivo, não o eximindo da multa do art. 14, parágrafo único, do CPC e da indenização do art. 18 do mesmo diploma.

Aspecto relevante concerne à indicação de bens para serem penhorados, âmbito no qual o juiz, por sua posição, depende da efetiva colaboração das partes para poder imprimir eficácia ao desenvolvimento da atividade executiva. A Lei n. ${ }^{0} 11.232$, alterando o CPC, facultou ao exequente nomear, desde logo, quando do requerimento da expedição do mandado de penhora, bens do executado passíveis de constrição. Possibilitou, dessa forma, que o próprio autor, atuando na defesa de seus interesses, efetue pesquisa prévia de bens e indique aqueles que foram localizados, de modo a tornar frutífera a diligência do Oficial. Trata-se de claro exemplo da cooperação da parte com o bom desenvolvimento da execução; com efeito, sendo do maior interesse do exequente encontrar bens penhoráveis, a sistemática tende a ser mais eficaz do que a da prévia nomeação de bens pelo executado, quando a tendência favorecia indicações procrastinatórias e de pouca seriedade. (GORON, 2011)

Conforme o art. 600, inciso IV do CPC, na redação da Lei n. ${ }^{\circ} 11.232$, a colaboração do devedor é incentivada mediante a instituição do dever de apontar onde estão os seus bens sujeitos à penhora. Referida previsão busca retirar dos ombros do exequente e do Judiciário a localização física dos bens, adotando a lógica mais simples de suscitar a colaboração da parte conhecedora da situação dos bens. Naturalmente, a colaboração da qual se cogita, porque presumivelmente contrária aos interesses do executado, mereceu o necessário reforço legal, tendo-se o não cumprimento do mencionado dever como ato atentatório à dignidade da justiça. $\mathrm{O}$ exame comparativo da legislação processual civil evidencia outros exemplos característicos de institutos cooperativos na execução por expropriação. A Ley de Enjuiciamento Civil espanhola prevê, no seu art. 640, a possibilidade de exequente e executado convencionarem o meio mais eficaz de transformação dos bens penhorados em dinheiro. A cooperação do executado no sentido da efetivação da penhora é igualmente prevista no art. 848-A do Código de Processo Civil português. (GORON, 2011)

A exploração do tema lança luzes sobre as decisões judiciais não autossuficientes e sobre a atividade judicial que as segue, voltada para a adequação da realidade sensível ao pronunciamento judicial. A compreensão de sua natureza jurisdicional determina que atividade material do juiz fique submetida ao regime constitucional do processo civil, 
integrando-a num modelo de processo essencialmente cooperativo. A colaboração das partes na concretização da decisão da causa é polarizada pelos valores da efetividade e da segurança, conferindo impulso, por um lado, aos atos destinados a efetivar as medidas materiais (coercitivas ou sub-rogatórias), e permitindo, por outro, o controle da legitimidade dos atos judiciais que atuam sobre a esfera jurídica do réu. A cooperação das partes, à luz do contraditório, mais do que condição de uma tutela efetiva dos direitos, constitui-se em pressuposto para o justo desenvolvimento da atividade material do juízo. (GORON, 2011)

Como bem apontado por Lívio G. Goron, como afirma Michele Taruffo, a "melhor" execução forçada é a execução que não se mostra necessária. (GORON, 2011) Isso se tivermos como premissa básica o dever de colaboração de todos os "atores do processo".

\section{REFERÊNCIAS}

ASSIS, Araken de. O contempt of court no direito brasileiro. Revista de Processo, São Paulo, n. 111, p. 18-37, jul-set, 2003.

ASSIS, Araken. Dever de veracidade das partes no processo civil. Disponível em:

$<$ http://www.rkladvocacia.com/arquivos/artigos/art_srt_arquivo20100810135544.pdf>. Acessado em: 13 maio 2011.

CARPENA, Márcio Louzada. Da não apresentação de bens passíveis de penhora e das multas. Disponível em: < http://www.abdpc.org.br/artigos/artigol071.htm>. Acessado em: 10 maio de 2011.

CARPENA, Márcio Louzada. Do processo cautelar moderno. 2.ed. Rio de Janeiro: Forense, 2005.

CARVALHO FILHO, Antônio. Obtenção transnacional de prova em matéria civil e comercial.

Disponível em: < http://www.abdpc.org.br/abdpc/artigos/Obten\%C3\%A7\%C3\%A3o\%20

transnacional\%20de $\% 20$ prova $\% 20 \mathrm{em} \% 20$ mat $\% \mathrm{C} 3 \%$ A9ria $\% 20$ civil $\% 20$ ou $\% 20$ comercial\%20-\%20 artigo.pdf $>$. Acessado em: 13 maio 2011.

DANGEL, Edward M. National lawyer's manual of contempt, incluing civil and criminal contempts. Boston: National Lawyer's Manual Company, 1939.

GORON, Lívio Goellner. Colaboração na concretização da decisão da causa. Biblioteca Digital Revista Brasileira de Direito Processual - RBDPro, Belo Horizonte, ano 19, n. 73, jan./mar. 2011. Disponível em: < http://www.bidforum.com.br/bid/PDI0006.aspx?pdiCntd=72028> . Acessado em: 21 jun. 2011.

HANBURY-YARDLEY, English Courts of Law, Oxford, 1979.

JACOB, The Fabric of English Civil Procedure, Londres, 1987.

MARINONI, Luiz Guilherme. Técnica processual e tutela dos direitos. 3.ed. São Paulo: Revista dos Tribunais, 2010.

MITIDIERO, Daniel. Colaboração no processo civil: pressupostos sociais, lógicos e éticos. São Paulo: Revista dos Tribunais, 2009. 
MORAES, Maria Celina Bodin de. Danos à pessoa humana. Rio de Janeiro: Renovar. 2003.

MOREIRA, José Carlos Barbosa. Revolução Processual Inglesa. Disponível em: http://www.iob.com. $\mathrm{br} / \mathrm{bibliotec}$ adigitalderevistas/bdr.dll?f=templates\&fn=main.htm\&2.0. Acessado em: 25 abr. 2011.

MOTTA, Cristina Reindolff da. Desacato a Ordem Judicial. 2002. 233 f. Dissertação (Mestrado em Ciências Jurídicas e Sociais) - Faculdade de Direito, Universidade Católica do Rio Grande do Sul, 2002.

OLIVEIRA. Carlos Alberto Alvaro de; MITIDIERO, Daniel Francisco. Curso de processo civil: volume1: teoria geral do processo civil e parte geral do direito processual civil. São Paulo: Atlas, 2010. PORTO, Sérgio Gilberto; USTÁRROZ, Daniel. Lições de direitos fundamentais no processo civil. Porto Alegre: Livraria do Advogado, 2009.

SILVA, Luiz Antônio Miranda Amorim. As astreintes e a improcedência da demanda. Revista da AGU, Brasília. v.7, n.15, p.148-168, mar., 2008.

TALAMINI, Eduardo. Tutela relativa aos deveres de fazer e de não fazer: e sua extensão aos deveres de entrega de coisa (CPC, arts. 461 e 461-A; CDC, art. 84). 2.ed. rev., atual e ampl. São Paulo: Revista dos Tribunais, 2003.

TARUFFO, Michele; HAZARD JÚNIOR, Geoffrey. Discovery and the role of the judge in civil law jurisdictions. Notre Dame Law Revue, n. 73, 1998.

TESHEINER, José Maria Rosa; MILHORANZA, Mariângela Guerreiro. Temas de direito e processos coletivos. Porto Alegre: HS Editora, 2010.

WAMBIER, Luiz Rodrigues; WAMBIER, Teresa Arruda Alvim; MEDINA, José Miguel Garcia. Breves comentários à nova sistemática processual civil: emenda constitucional n. 45/2004 (reforma do judiciário); Lei 10.444/2002; Lei 10.358/2001 e Lei 10.352/2001. 3.ed. São Paulo: Editora Revista dos Tribunais. 2005.

\section{OBRAS CONSULTADAS}

MARINONI, Luiz Guilherme. Da ação abstrata e uniforme à ação adequada à tutela dos direitos. In: MACHADO, Fábio Cardoso; AMARAL, Guilherme Rizzo (Org.). Polêmica sobre a ação: a tutela jurisdicional na perspectiva das relações entre direito e processo. Porto Alegre: Livraria do Advogado, 2006.

MARINONI, Luiz Guilherme. Técnica processual e tutela dos direitos. 2. ed. rev. atual. São Paulo: Revista dos Tribunais, 2008.

MARINONI, Luiz Guilherme; MITIDIERO, Daniel. Código de Processo Civil: comentado artigo por artigo. São Paulo: Revista dos Tribunais, 2008.

MENDES, Gilmar Ferreira; COELHO, Inocêncio Mártires; BRANCO, Paulo Gustavo Gonet. Curso de direito constitucional. São Paulo: Saraiva, 2007.

MITIDIERO, Daniel. Colaboração no processo civil: pressupostos sociais, lógicos e éticos. São Paulo: Revista dos Tribunais, 2009.

MITIDIERO, Daniel. Comentários ao Código de Processo Civil. São Paulo: Memória Jurídica, 2004. t. I.

MITIDIERO, Daniel. Elementos para uma teoria contemporânea do processo civil brasileiro. Porto Alegre: Livraria do Advogado, 2005. 
MITIDIERO, Daniel. Por uma nova teoria geral da ação: as orientações unitárias e a orientação dualista da ação. Revista de Direito Processual Civil Gênesis, Curitiba, v. 7, n. 26, p. 711-734, out./dez. 2002.

MOREIRA, José Carlos Barbosa. A sentença mandamental: da Alemanha ao Brasil. In: Temas de direito processual: sétima série. São Paulo: Saraiva, 2001. OLIVEIRA, Carlos Alberto Álvaro de. Direito material, processo e tutela jurisdicional. In: MACHADO, Fábio Cardoso; AMARAL, Guilherme Rizzo (Org.). Polêmica sobre a ação: a tutela jurisdicional na perspectiva das relações entre direito e processo. Porto Alegre: Livraria do Advogado, 2006.

OLIVEIRA, Carlos Alberto Álvaro de. O processo civil na perspectiva dos direitos fundamentais. Revista de Processo, São Paulo, ano 29, n. 113, p. 9-21, jan./fev. 2004.

OLIVEIRA, Carlos Alberto Álvaro de. Teoria e prática da tutela jurisdicional. Rio de Janeiro: Forense, 2008.

SILVA, Ovídio Araújo Baptista da. Curso de processo civil. 6. ed. rev. atual. Rio de Janeiro: Forense, 2008. v. 1, t. II.

SILVA, Ovídio Araújo Baptista da. Direito material e processo. In: MACHADO, Fábio Cardoso; AMARAL, Guilherme Rizzo (Org.). Polêmica sobre a ação: a tutela jurisdicional na perspectiva das relações entre direito e processo. Porto Alegre: Livraria do Advogado, 2006.

SILVA, Ovídio Araújo Baptista da. Jurisdição e execução na tradição romano-canônica. 2. ed. rev. São Paulo: Revista dos Tribunais, 1998. SILVA, Ovídio Araújo Baptista da. Processo e ideologia: o paradigma racionalista. Rio de Janeiro: Forense, 2004.

TARUFFO, Michele. A atuação executiva dos direitos: perfis comparatísticos. Tradução de Teresa Celina de Arruda Alvim Pinto. Revista de Processo, São Paulo, ano 15, n. 59, p. 72-97, jul./set. 1990.

TARUFFO, Michele. Note sul diritto alla condenna e all'esecuzione. Revista de Processo, São Paulo, ano 32 , n. 144, p. 57-84, fev. 2009. ZANETI JÚNIOR, Hermes. Processo constitucional: o modelo constitucional do processo civil. Rio de Janeiro: Lumen Juris, 2007. 